\title{
OLD ENGLISH POETICAL ARCHETYPES
}

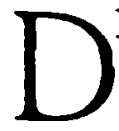

R. GREG'S review of my pamphlet (see The Library, June 1920, pp. 58-6I) is highly gratifying to me. I am glad to find that a critic so peculiarly qualified to judge in such a matter is able to accept my proof that many Old English poems were copied from manuscripts written on loose sheets uniform in quantity of writing, and regularly ending with the conclusion of a sentence and a verse. That he should refuse to follow me in the conclusion that these curious phenomena indicate the method of composition of the Old English poets does not surprise me. This conclusion would admittedly be improbable apart from the positive evidence in its favour. But I must continue to regard it as established, unless some other way can be found of completely accounting for the facts; and it does not appear that Dr. Greg has done this even to his own satisfaction. His criticism of the table on p. 8 is certainly justified; and he is probably right in objecting to my suggested explanation of the position of the $\mathrm{X}$ in the margin of the manuscript. (This explanation, however, was proposed only as the less likely of two alternatives.)

My purpose in the present writing, however, is not to comment on the review, but to confess and rectify a mistake of my own which my critic has not pointed out. In the Old English paraphrase of Genesis, the story of the creation of Eve (Gen. ii. 21-2) comes before the account of Paradise and its rivers (Gen. ii. 8-I4). I erroneously assumed that this inversion of the Bible order was due to a dislocation in the text of the paraphrase, and suggested that two leaves of the extant manuscript had changed places when the 
volume was being repaired. Further consideration has convinced me that the transposition is due to the difficulties which the paraphrast found in dealing with the duplicate accounts of the creation in the first two chapters of the Bible. When he came to the words 'masculum et feminam creavit eos' in Gen. i. 27, he felt that he could not leave this summary statement without amplification. He therefore imported the account of the making of woman from the second chapter, but after this returned to the original sequence. The supposed dislocation in the text of the paraphrase is therefore non-existent, so that I need not dispute with Dr. Greg as to the likeliest way of accounting for it.

I may here mention that Professor Craigie has pointed out to me that I was wrong in regarding the 'Daniel' poem as an insoluble exception to my theory of the origin of the numbered sections. When due allowance is made for the insertion of the 'Azarias' from another manuscript, the figures work out correctly.

Henry Bradiey. 